\title{
EFFECT OF IRRIGATION REGIME AND POTASSIUM FERTILIZER RATES ON GROWTH,YIELD, OIL COMPOSITION AND SOME WATER RELATIONS OF FENNEL PLANT (Foeniculum vulgare Mill) UNDER MIDDLE EGYPT CONDITIONS
}

(Received:13.5.2015)

\author{
By \\ Y. A. M. Hafiz and M. M. Ewis * \\ Medicinal and Aromatic Plants Research Department, Horticulture Research Institute \\ *Requirements and Field Irrigation Research Department, Soils \& Water and \\ Envieronmemt Research Institute, Agricultural Research Center, Giza, Egypt
}

\begin{abstract}
Two field experiments were conducted during two successive seasons of 2012/2013 and 2013/2014 at Sids Horti. Res. Station, Beni-Sweif Governorate to study the effect of irrigation regime and potassium fertilizer rates on growth, yield and essential oil of fennel plants, water consumptive use (C.U.) and water use efficiency (W.U.E.). The treatments were three levels of moisture regime (irrigation at 25-30, 50-55 and 75-80\% of available soil moisture depletion) combined with three potassium fertilizer levels $\left(0,24\right.$ and $48 \mathrm{~kg} \mathrm{~K}_{2} \mathrm{O} / \mathrm{fed}$.) as potassium sulphate $\left(48 \% \mathrm{~K}_{2} \mathrm{O}\right)$. A split plot design with four replications was used, irrigation treatments occupied the main plots, while potassium levels arranged in sub-plot. The results obtained showed that:

1-Increasing soil moisture depletion from $25-30 \%$ to $75-80 \%$ significantly decreased plant height, stem diameter, weight of 1000 seeds and percentage of essential oil in both seasons.

2-Increasing potassium levels from zero to $48 \mathrm{~kg} \mathrm{~K}_{2} \mathrm{O}$ /fed. significantly increased all the studied plant characters as well as improved water consumptive use and water use efficiency. Concerning essential oil constituents, methyl chavicol (estragole) was the major compound, followed by limonene, fenchone, anethole, $\alpha$ pinene, fenchyl acetate, myrcene, $\beta$-pinene, comphene and camphor.

3-Irrigation at 50-55\% soil moisture depletion $\left(\mathrm{I}_{2}\right)$ produced the greatest values of the number of branches/plant, the number of umbels/plant, fruits yield per plant and feddan, oil yield per plant and feddan and water use efficiency in both seasons.

4-The highest values of the amount of applied water and water consumptive use were recorded when plants were subjected to irrigation at $25-30 \%$ soil moisture depletion $\left(I_{1}\right)$.

5-Most of the water consumed was removed from the upper soil layer $(0-30 \mathrm{~cm})$ of soil profile.
\end{abstract}

Key words: Foenciulum vulgare, irrigation regimes, potassium fertilizer, oil yield, essential oil and water relations.

\section{INTRODUCTION}

Bitter fennel (Foeniculum vulgare var. vulgare Mill) is a winter annual herb belonging to the Umbelliferae (Apiaceae) Family. It is one of the most widely cultivated medicinal and aromatic plants in Egypt, known and used by humans since antiquity. Because of its flavor, it was cultivated in the countries surrounding the Mediterranean Sea. Fennel is one of the oldest field crops used by the Egyptians for medicinal purposes. Most of the area cultivated with fennel is located in Mid-Southern Egypt (Beni-Sweif, El-Fayoum, Menia and Assiut Governorates) as reported by A.E.B.(2007). Only one strain of common fennel (Foeniculum vulgare, Mill) was cultivated in Egypt for the national and international purposes. The cultivar yields large fruits and reasonable percentage of essential oil with particularly high estragole content, but it is poor in fenchone which is an important constituent of the fennel essential oil. Other cultivars were grown under Egyptian environmental conditions; with good yields of fenchone content (Massoud, 1992). Essential oil of fennel also has an inhibitory effect on the activity of ileum, the urinary bladder and against 
spasmogens (Saleh et al., 1996). Trans-anethole, estragole, fenchone and limonene are the major constituents of the essential oil of bitter fennel fruits as reported by Venskutonis et al. (1996).

Antioxidant and antimicrobial activity of fennel has also been reported by Ruberto et al. (2000). The seeds have a traditional reputation as an aid to weight loss and longevity. The major constituent of fennel oil is anethole (Braun and Franz 1999).

Water is the most limiting natural resources for agricultural production in arid and semi-arid regions. Nowadays the total annual water resources of Egypt are about 67.27 billon $\mathrm{m}^{3}$ Abo Zied (2000). The agricultural sector consumes almost $80-90 \%$ of the total water allocated to Egypt. The ever increasing of the Egyptian population and the limited water resources led to a steady decrease in per capita share of water. Therefore, there is a need for decreasing plant water consumption through, using more efficient irrigation methods, (Tayel et al., 2007), plant breeding technology, longer irrigation intervals, higher moisture depletion,skipping irrigation during the early vegetative growth or during maturation stage, and timing the length of irrigation interval with the stage of plant growth, Faki (1991).

Potassium is considered one of the major nutrient and it is very important element in growth and development of plants. It is necessary in young growing tissues for cell elongation and possibly for cell division. It is very mobile in plants and therefore circulates freely and has vital role in maintenance of turgor pressure. It helps in several physiological processes and uptake of other nutrient elements Mengel and Kirkby (1987). It also plays an important role in activation of more than 60 enzyme systems in plants. It has a role in stomatal respiration, photosynthetic transfer and crop development. Since intensive use of farm land might go along with mismanagement leading to loss of soil fertility and together with these reduction of physical and microbiological soil parameters, under these conditions making fertilization of the soil with potassium is important to avoid plants reduction symptoms. In addition, it also plays an important role in irrigation where it helps plants to be tolerant for water stress. Plants depend upon $\mathrm{K}$ to regulate the opening and closing of stomata, the pores through which leaves exchange carbon dioxide $\left(\mathrm{CO}_{2}\right)$, water vapor, and oxygen $\left(\mathrm{O}_{2}\right)$ with the atmosphere. Proper functioning of stomata is essential for photosynthesis, water and nutrient transport and plant cooling. When $\mathrm{K}$ moves into the guard cells around the stomata, the cells accumulate water and swell, causing the pores to open and allowing gases to move freely in and out. When water supply is short, $\mathrm{K}$ is pumped out of the guard cells. The pores close tightly to prevent loss of water and minimize drought stress to the plant (Thomas and Thomas, 2009). If $\mathrm{K}$ supply is inadequate, the stomata become sluggish - slow to respond - and water vapor is lost. Closure may take hours rather than minutes and is incomplete. As a result, plants with an insufficient supply of $\mathrm{K}$ are much susceptible to water stress. Accumulation of $\mathrm{K}$ in plant roots produces a gradient of osmotic pressure that draws water into the roots. Plants deficient in $\mathrm{K}$ are thus less able to absorb water and are more subject to stress when water is in short supply (Mengel and Kirkby, 1987).

Drought is a major environmental stress that affects plant morphology, physiology and biochemistry, causing a significant reduction in agricultural production Hsiao (1973) and Tyree and Karamanos (1981). Although the effects of drought on many plants have been widely investigated, less is known about the biosynthesis and accumulation of oil in aromatic plants under water deficit conditions Sangwan et al. (1993). Letchamo et al. (1995) found that there was a significant reduction in dry matter and relative growth rate of Thymus vulgaris grown under drought stress and Patel et al. (2000). Sangwan et al. (1994) exposed Cymbopogon nardus and Confertiflorus pendulus to water stress. They found that water deficit reduced plant height, leaf length, leaf area, fresh and dry weights, and moisture content. The percentage oil content was significantly affected depending on the water stress treatment of Origanum majorana, where higher oil content and leaf dry weight were produced with increasing soil moisture deficit, Rhizopoulou and Diamantoglou (1991) and Mohamed and Abdue (2004) showed that water stress imposed by restricting the number of irrigations significantly decreased plant height, branch number, and fruit and oil yield, whereas it increased the percentage volatile oils. Younis et al. (2010) showed that supplying plants with a water level of $40 \%$ from available soil water and $30 \mathrm{~kg} \mathrm{~K} \mathrm{~K}_{2} \mathrm{O} / \mathrm{fed}$ were effective on raising the productivity of fruit yield and essential oil of fennel plant. 
The aim of the current work was to investigate the effect of irrigation regimes and potassium fertilizer on the productivity, essential oil \%, constituents and soil-water relations of fennel.

\section{MATERIALS AND METHODS}

Two year study were carried out at Sids Horticultural Research Station, A.R.C., BeniSweif Governorate (Middle Egypt, Lat. 29 ${ }^{\circ}$ 04' $\mathrm{N}$, Long. $31^{\circ} 06^{\prime} \mathrm{E}$ and $30.40 \mathrm{~m}$ above the mean sea level) during the two successive seasons of 2012/2013 and 2013/2014.

The soil of the experimental sites was clay loam in texture, with water table level (using observation well) ranged between 1.60-1.85 m., $\mathrm{EC}$ in soil paste and $\mathrm{pH}$ in 1:2.5 water-soil suspension were $0.45 \mathrm{ds}^{-1}$ and 7.9, respectively. The levels of available N,P and $\mathrm{K}$ were $34.37,10.74$ and 206.5 ppm., respectively and organic matter was $1.71 \%$ (Jackson, 1967).

A split-plot design with three replication was followed. The main plots were occupied by irrigation regimes, i.e., 25-30, 50-55 and 75-80\% from available soil moisture depletion $\left(\mathrm{I}_{1}, \mathrm{I}_{2}\right.$ and $\mathrm{I}_{3}$ ), while the sub-plots were assigned for three potassium rates, i.e., 0,24 and $48 \mathrm{~kg} \mathrm{~K}_{2} \mathrm{O} / \mathrm{fed}$. $\left(\mathrm{K}_{1}, \mathrm{~K}_{2}\right.$ and $\left.\mathrm{K}_{3}\right)$, in the form of potassium sulphate $\left(48 \% \mathrm{~K}_{2} \mathrm{O}\right)$. Sub-plot area was $10.5 \mathrm{~m}^{2}$ including 5 ridges, $3.5 \mathrm{~m}$ long and $60 \mathrm{~cm}$. apart. Seeds of fennel were obtained from the Medicinal and Aromatic Plants Department, Agricultural Research Center, Egypt and sowing took place on 15 and 13 October in the two seasons, respectively. Fennel seeds were sown in hills at $40 \mathrm{~cm}$. apart on one side of ridges. The seedlings were thinned to one seedling/hill after 45 days from sowing. Nitrogen fertilization at the rate of $200 \mathrm{~kg}$ ammonium sulphate $(20.5 \% \mathrm{~N})$ was added at two portions; the first one was added after thinning 45 days from sowing before the following irrigation, the other was added after 90 days from sowing. Also, $200 \mathrm{~kg} / \mathrm{fed}$. as calcium superphosphate $\left(\begin{array}{llll}15.5 & \% & \mathrm{P}_{2} & \mathrm{O}_{5}\end{array}\right)$ was applied during preparation of the soil.

Some metrological data of the experimental site during the two growth seasons are illustrated in Table (1).

The plants were harvested on 10 and 17 May in both seasons and the following data were recorded:
2.1. Vegetative growth characters
1. Plant height $(\mathrm{cm})$.
2. Stem diameter $(\mathrm{cm}$.)

3. Number of branches/plant.

\subsubsection{Flowering and yield characters}

1. Number of umbels/plant.

2. Weight of 1000 seeds (g).

3. Fruit yield/plant (g).

4. Fruit yield (kg/fed.).

\subsubsection{Essential oil}

1.Essential oil percentage

2. Essential oil yield/plant(ml)

3. Essential oil yield/fed.(L)

4. Essential oil constituents by GC/MS.

Essential oil \% of fennel fruits was determined using a Clevenger-Type apparatus according to British Pharmacopoeia (1963). The samples were dehydrated over anhydrous sodium sulphate. Essential oil yield/fed. was calculated by multiplying oil (\%) by fennel fruit yield/plant. The essential oil constituents were determined by subjected to GC/MS. Separation of the resulting crude, fractions and volatile oil was accomplished on a Varian Gas Chromatograph (Walnut Creek, California, USA) equipped with Finnegan mat SSQ 700 (Thermo Inst., USA) mass spectrometer and a 30 $\mathrm{cm} \times 0.25 \mathrm{~mm}$. DB-5 capillary column film thickness (J \& W Scientific, USA). The column temperature was programmed from $50 \mathrm{C}$ (constant for $3 \mathrm{~min}$.), at a rate of $7 \mathrm{C} / \mathrm{min}$ to 250 $00 \mathrm{C}$ with $10 \mathrm{~min}$ isothermal hold. The injector 0 temperature was $220^{\circ} \mathrm{C}$ and the transition time 0 temperatures was $250^{\circ} \mathrm{C}$. The carrier gas was helium 0 and the column head pressure was 10 15 psi. The identification of the constituents was determined by comparing the spectrum with the other stored in Wiley Mass Spectral Library containing over 147000 volatile compounds used according to (Robert, 1995).

\subsubsection{Soil-water relations}

Soil moisture content was gravimetrically determined in soil samples taken from consecutive depths of $15 \mathrm{~cm}$. down to a depth of $60 \mathrm{~cm}$. Soil samples were also collected just before each irrigation, 48 hours after irrigation and at harvest time. Irrigation water was applied when the moisture content reached the desired available soil moisture in each treatment. Field capacity was determined in the field (Garcia, 1978). Permanent wilting point and bulk density were executed according to Black et al. (1985) to a depth of $60 \mathrm{~cm}$. Available soil moisture was calculated by subtracting wilting point from field capacity. The average values are presented in Table (2).

\subsubsection{Amount of irrigation water applied}

The amount of water applied at each 
Table (1): Average climatic data for Beni-Sweif area during the two growing seasons.

\begin{tabular}{|c|c|c|c|c|c|c|}
\hline Month & T. max. & T. min. & W. S. & R. H. & R. F. & E. pan \\
\hline October & 30.9 & 18.9 & 1.9 & 54 & 0.0 & 5.5 \\
\hline November & 26.1 & 13.3 & 1.2 & 58 & 0.1 & 3.3 \\
\hline December & 22.0 & 12.5 & 1.3 & 61 & 0.7 & 2.0 \\
\hline January & 20.5 & 8.6 & 1.0 & 60 & 1.3 & 2.1 \\
\hline February & 21.7 & 9.4 & 1.2 & 59 & 0.6 & 2.5 \\
\hline March & 25.4 & 11.3 & 1.2 & 55 & 0.6 & 4.0 \\
\hline April & 30.2 & 14.8 & 1.8 & 53 & 0.6 & 5.4 \\
\hline May & 33.0 & 19.5 & 1.5 & 51 & 0.0 & 7.5 \\
\hline
\end{tabular}

T. max. T. min. = Maximum and minimum temperatures ${ }^{\circ} \mathrm{C} ;$ W. S. = Wind speed $(\mathrm{m} / \mathrm{sec})$;

R. H.= Relative humidity $(\%) ; \quad$ R. F. $=$ Rain fall $(\mathrm{mm} / \mathrm{month})$ and $\quad$ E. pan $=$ Evaporation pan $(\mathrm{mm} / \mathrm{day})$.

Table (2): Field capacity, wilting point, and available soil moisture content of the experimental field.

\begin{tabular}{|c|c|c|c|c|c|}
\hline Season & Soil depth $(\mathrm{cm})$ & $\begin{array}{c}\text { Field } \\
\text { capacity }(\%)\end{array}$ & $\begin{array}{c}\text { Wilting point } \\
(\%)\end{array}$ & $\begin{array}{l}\text { Available soil } \\
\text { moisture (\%) }\end{array}$ & $\begin{array}{c}\text { Bulk density } \\
\mathrm{g} / \mathrm{cm}^{3}\end{array}$ \\
\hline \multirow{4}{*}{$2012 / 2013$} & $0-15$ & 40.94 & 19.49 & 21.45 & 1.180 \\
\hline & $15-30$ & 37.88 & 18.03 & 19.85 & 1.243 \\
\hline & $30-45$ & 36.80 & 17.52 & 19.28 & 1.278 \\
\hline & $45-60$ & 32.55 & 15.50 & 17.05 & 1.315 \\
\hline \multicolumn{2}{|l|}{ Mean } & 37.04 & 17.64 & 19.41 & 1.254 \\
\hline \multirow{4}{*}{$2013 / 2014$} & $0-15$ & 42.40 & 20.00 & 22.40 & 1.176 \\
\hline & $15-30$ & 35.90 & 18.80 & 17.10 & 1.244 \\
\hline & $30-45$ & 33.45 & 15.00 & 18.45 & 1.251 \\
\hline & $45-60$ & 31.71 & 14.50 & 17.21 & 1.431 \\
\hline \multicolumn{2}{|c|}{ Mean } & 35.86 & 17.08 & 18.79 & 1.276 \\
\hline
\end{tabular}

irrigation was determined on the basis of raising 22.1. 3.2.Consumptive use (C.U.)

the soil moisture content to its field capacity plus $10 \%$ as leaching requirements. Irrigation water applied was calculated according to the following equation (Michael, 1978).

$$
\mathrm{d}=\mathrm{D}^{*} \mathrm{Bd}^{*} \frac{\mathbf{F}_{\mathrm{c}}-\mathbf{M}_{\mathrm{c}}}{\mathbf{1 0 O}}
$$

Where:

$\mathrm{d}=$ amount of water to be applied during an irrigation event, $\mathrm{cm}$.

$\mathrm{D}=$ soil depth within the root zone, $60 \mathrm{~cm}$.

$\mathrm{Bd}=$ soil bulk density, $\mathrm{g} \mathrm{cm}^{-3}$

$\mathrm{Fc}=$ field capacity moisture content $(\%$ by weight).

$\mathrm{Mc}=$ moisture content before irrigation $(\%$ by weight).

Submerged flow orifice with fixed dimension was used to measure the amount of water applied according to the following equation (Michael, 1978).

Where:

$$
\mathrm{Q}=\mathrm{CA} \sqrt{2 \mathrm{gh}}
$$

$\mathrm{Q}=$ discharge through orifice, $(\mathrm{L} / \mathrm{sec}$.).

$\mathrm{C}=$ coefficient of discharge, $(0.61)$.

$\mathrm{A}=$ cross-sectional area of the orifice, $\left(\mathrm{cm}^{2}\right)$.

$\mathrm{G}=$ acceleration of gravity, $\left(981 \mathrm{~cm} / \mathrm{sec}^{2}\right)$.

$\mathrm{H}=$ pressure head, causing discharge through the orifice $(\mathrm{cm})$.
Water consumptive use was calculated according to Doorenbos et al. (1979) as the following equation:

$$
\text { C.U. = ------------- } \text { x Bd x d }
$$

Where:

C.U. = actual water consumptive use in $\mathrm{cm}$.

$\mathrm{Q}_{2}=$ soil moisture content after 48 hours from irrigation (\%).

$\mathrm{Q}_{1}=$ soil moisture content before irrigation $(\%)$.

$\mathrm{Bd}=$ bulk density of the specified soil layer $\left(\mathrm{g} / \mathrm{cm}^{3}\right)$.

$\mathrm{d}=$ depth of soil layer $(\mathrm{cm})$.

\subsubsection{Water use efficiency (W.U.E.)}

Water use efficiency was calculated according to to Vites (1965) as follow:-

$$
\text { W.U.E. = Y / C.U. }
$$

Where:

$\mathrm{Y}=$ Fruits yield $(\mathrm{kg} / \mathrm{fed}$.$) .$

C.U. = Water consumptive use $\left(\mathrm{m}^{3} / \mathrm{fed}\right)$

2.2.Soil moisture extraction pattern (SMEP)

It was calculated according to the following equation, Israelson and Hansen (1962).

SMEP = C.U. (layer) x $100 /$ C.U. (seasonal)

Where:

C.U. (layer) = sum of extracted soil moisture in each soil layer $(15 \mathrm{~cm}$.). 
C.U. $($ seasonal $)=$ total sum of moisture extracted in all soil layers $(60 \mathrm{~cm}$.).

\subsection{Statistical analysis}

Data were statistically analyzed according to Snedecor and Cochran (1980).

\section{RESULTS AND DISCUSSION}

\subsection{Vegetative growth characters}

Data presented in Table (3) indicated that increasing the percentage of depleted water from available water decreased both plant height and stem diameter. The highest mean values due to irrigation treatments were recorded with plants that received the highest amounts of water $\left(\mathrm{I}_{1}\right)$ irrigation at $25-30 \%$ of available soil moisture depletion. The reduction in plant growth in the case longer irrigation cycles could be in part due to limiting the plant ability to absorb nutrients needed for optimal growth and development of plant. Also, it is well recognized that water is not only required for different biochemical activities of all cells, but also awakes generated turgor pressure in a driving force of cell expiation (Xiong and Zhu, 2002). Thus, water deficit disturbs normal cellular activities and restricts plant growth. Similar results were obtained by many workers such as Singh et al. (2005), Ashry et al. (2012) and Hamoda et al. (2014). On the other hand, the data revealed that the highest values of branches/plant were produced under irrigated the plants at $50-55 \%$ of available soil moisture depletion $\left(\mathrm{I}_{2}\right)$.

Regarding potassium effect, data showed that increasing potassium doses up to $48 \mathrm{~kg} \mathrm{~K}_{2} \mathrm{O} / \mathrm{fed}$. significantly increased plant height, stem diameter and the number of branches/plant in both seasons. These results are mainly due to potassium enhances many nutrient absorb, improving many physiological growth, support many of the crucial enzyme processes, transport of sugar and other products of photosynthesis from leaves to storage organs (Mengel and Kirkby, 1987). These results are in harmony with those found by Fodor and Kadlicsko (2006) who concluded that increasing the rates of NPK fertilization improved most of the growth parameters of white mustard.

The interaction effect was significant in both seasons for the studied growth characters, except for stem diameter. The highest values of plant height and stem diameter were produced from the treatment of irrigation at $25-30 \%$ of the available soil moisture depletion $\left(\mathrm{I}_{1}\right)$ and fertilized with $48 \mathrm{~kg} \mathrm{~K}_{2} \mathrm{O} / \mathrm{fed} .\left(\mathrm{K}_{3}\right)$ in both seasons. While, the fennel plants irrigated at 50-
$55 \%$ of available soil moisture depletion $\left(\mathrm{I}_{2}\right)$ and received $48 \mathrm{~kg} \mathrm{~K}$ O/fed. recorded the highest values of the number of branches/plant.

\subsubsection{Flowering and yield characters}

3.1.1.1. Number of umbels and weight of $\mathbf{1 0 0 0}$ seeds

Data in Table (4) showed that the number of umbels/plant and weight of 1000 seeds were significantly influenced by irrigation regimes in the two growing seasons. The irrigation at 50$55 \%$ of available soil moisture depletion $\left(\mathrm{I}_{2}\right)$ produced the highest number of umbels/plant as 63.24 and 60.24/plant in both seasons, respectively, while irrigation at $25-30 \%$ of available soil moisture depletion $\left(\mathrm{I}_{1}\right)$ produced the heaviest weight of 1000 seeds (10.60 and $10.32 \mathrm{~g}$ ) in both seasons, respectively. The superiority of the effect of $I_{2}$ treatment on the number of umbels/plant is mainly due to its effect on the number of branches (Table 3). It is obvious notice that the difference between the effect of irrigation regimes $I_{2}$ and $I_{1}$ on both the number of umbels/plant and 1000 seeds weight is not significant in both seasons. These results are in agreement with those of Champolivier and Merrien (1996) who reported that water stress affected one thousand seeds weight in rapeseed (Brassica napus).

The application of $48 \mathrm{~kg} \mathrm{~K}_{2} \mathrm{O} / \mathrm{fed} .\left(\mathrm{K}_{3}\right)$ produced the highest number of umbels/plant and weight of 1000 seeds compared to the other two potassium treatments. A sufficient supply of potassium is required for each plant cell to its proper function. Generally, the enhancing effect of K-rate fertilization on plant growth may be due to the positive effects of potassium on activation of photosynthesis and metabolic processes of organic compounds in plants. The increase in the number of umbels/plant and weight of 1000 seeds due to potassium fertilization is in agreement with the results reported by Mohamed and Abdue (2004) on fennel plant.

The interaction effects on the number of umbles/plant and weight of 1000 fruits were significant in both seasons. The highest values of the number of umbles/plant was produced owing to irrigation at depletion of $50-55 \%$ from the available water $\left(I_{2}\right)$, while the highet weight of 1000 seeds was produced from irrigation at 25$30 \%$ of available soil moisture depletion $\left(\mathrm{I}_{1}\right)$ under $48 \mathrm{~kg} \mathrm{~K}_{2} \mathrm{O} / \mathrm{fed}$. In both seasons On the other hand, the plants fertilized with the lowest potassium rate and water stress exerted the lowest number of umbels/plant. 
Table (3): Effect of irrigation regimes and potassium fertilization on plant height (cm), stem diameter (cm) and the number of branches/plant of fennel plants during 2012/2013 and 2013/2014 seasons.

\begin{tabular}{|c|c|c|c|c|c|c|c|}
\hline \multirow{2}{*}{$\begin{array}{l}\text { Irrigation } \\
\text { regimes (I) }\end{array}$} & \multirow{2}{*}{$\begin{array}{c}\text { Potassium } \\
\text { rates } \\
\text { (K) }\end{array}$} & \multicolumn{3}{|c|}{ First season } & \multicolumn{3}{|c|}{ Second season } \\
\hline & & $\begin{array}{c}\text { Plant } \\
\text { height } \\
(\mathrm{cm})\end{array}$ & $\begin{array}{c}\text { Stem } \\
\text { diameter } \\
(\mathrm{cm})\end{array}$ & $\begin{array}{c}\text { No. of } \\
\text { branches/ } \\
\text { plant }\end{array}$ & $\begin{array}{c}\text { Plant } \\
\text { height } \\
(\mathrm{cm})\end{array}$ & $\begin{array}{c}\text { Stem } \\
\text { diameter } \\
(\mathrm{cm})\end{array}$ & $\begin{array}{c}\text { No. of } \\
\text { branches/ } \\
\text { plant }\end{array}$ \\
\hline \multirow{3}{*}{$\mathbf{I}_{1}$} & $\mathbf{K}_{1}$ & 185.5 & 3.32 & 23.23 & 177.8 & 3.18 & 22.57 \\
\hline & $\mathbf{K}_{2}$ & 199.5 & 3.56 & 24.30 & 185.5 & 3.41 & 24.03 \\
\hline & $K_{3}$ & 214.0 & 3.63 & 25.03 & 191.0 & 3.45 & 24.67 \\
\hline \multicolumn{2}{|c|}{ Mean } & 199.7 & 3.50 & 24.19 & 184.8 & 3.35 & 23.76 \\
\hline \multirow{3}{*}{$\mathbf{I}_{2}$} & $\mathbf{K}_{1}$ & 155.5 & 3.14 & 23.73 & 145.0 & 3.01 & 23.25 \\
\hline & $\mathbf{K}_{2}$ & 177.5 & 3.36 & 24.36 & 163.5 & 3.29 & 24.57 \\
\hline & $\mathbf{K}_{3}$ & 194.3 & 3.44 & 25.23 & 177.8 & 3.36 & 25.53 \\
\hline \multicolumn{2}{|c|}{ Mean } & 175.8 & 3.31 & 24.44 & 162.1 & 3.22 & 24.45 \\
\hline \multirow{3}{*}{$\mathbf{I}_{3}$} & $\mathbf{K}_{1}$ & 130.0 & 3.11 & 23.03 & 120.3 & 2.92 & 22.43 \\
\hline & $\mathbf{K}_{2}$ & 141.3 & 3.27 & 23.33 & 129.8 & 3.19 & 23.23 \\
\hline & $\mathbf{K}_{3}$ & 156.3 & 3.33 & 24.30 & 148.5 & 3.30 & 24.03 \\
\hline \multicolumn{2}{|c|}{ Mean } & 142.5 & 3.24 & 23.55 & 132.9 & 3.14 & 23.23 \\
\hline Mean of & $K_{1}$ & 157.0 & 3.19 & 23.33 & 147.7 & 3.04 & 22.75 \\
\hline potassium & $\mathbf{K}_{2}$ & 172.8 & 3.40 & 24.00 & 159.6 & 3.30 & 23.94 \\
\hline rates & $\mathbf{K}_{\mathbf{3}}$ & 188.2 & 3.47 & 24.85 & 172.4 & 3.37 & 24.74 \\
\hline L.S.D & Irrig.(I) & 24.7 & 0.26 & 0.86 & 23.1 & 0.20 & 0.91 \\
\hline at $5 \%$ & Ferti (K) & 26.3 & 0.28 & 0.92 & 24.7 & 0.27 & 0.96 \\
\hline & I X K & 52.1 & N.S & 1.73 & 50.4 & N.S & 1.69 \\
\hline
\end{tabular}

$\left(I_{1}, I_{2}\right.$ and $\left.I_{3}\right)$ irrigation at : $25-30$, and $75-80 \%$ of available soil moisture depletion; $\left(K_{1}, K_{2}\right.$ and $\left.K_{3}\right)$ potassium fertilizer: 0,24 and $48 \mathrm{~kg} \mathrm{~K} \mathrm{~K}_{2} \mathrm{O} / \mathrm{fed}$., respectively

Table (4): Effect of irrigation regimes and potassium fertilization on the number of umbels/plant, weight of 1000 seeds (g), fruit yield/plant (g) and fruit yield/fed. (kg) of fennel plant in 2012/2013 and 2013/2014 seasons.

\begin{tabular}{|c|c|c|c|c|c|c|c|c|c|}
\hline \multirow[b]{2}{*}{$\begin{array}{l}\text { Irrigation } \\
\text { regimes } \\
\text { (I) }\end{array}$} & \multirow[b]{2}{*}{$\begin{array}{c}\text { Potassium } \\
\text { rates } \\
(\mathbf{K})\end{array}$} & \multicolumn{4}{|c|}{ First season } & \multicolumn{4}{|c|}{ Second season } \\
\hline & & $\begin{array}{c}\text { No. of } \\
\text { umbels/ } \\
\text { plant }\end{array}$ & $\begin{array}{c}\text { Weight } \\
\text { of } 1000 \\
\text { seeds }(\mathrm{g})\end{array}$ & $\begin{array}{c}\text { Fruits } \\
\text { yield/ } \\
\text { plant (g) }\end{array}$ & $\begin{array}{c}\text { Fruits } \\
\text { yield/ } \\
\text { fed. (kg) }\end{array}$ & $\begin{array}{c}\text { No. of } \\
\text { umbels } \\
\text { plant }\end{array}$ & $\begin{array}{c}\text { Weight } \\
\text { of } 1000 \\
\text { seeds (g) }\end{array}$ & $\begin{array}{c}\text { Fruits } \\
\text { yield/ } \\
\text { plant(g) }\end{array}$ & $\begin{array}{c}\text { Fruits } \\
\text { yield/ } \\
\text { fed. }(\mathrm{kg})\end{array}$ \\
\hline \multirow{3}{*}{$\mathbf{I}_{1}$} & $K_{1}$ & 58.15 & 9.14 & 51.19 & 852.96 & 55.90 & 8.89 & 43.88 & 729.84 \\
\hline & $\mathbf{K}_{2}$ & 61.51 & 10.51 & 54.23 & 904.00 & 58.66 & 10.13 & 49.37 & 836.96 \\
\hline & $\mathbf{K}_{3}$ & 63.53 & 12.15 & 65.64 & 1092.24 & 60.51 & 11.95 & 54.85 & 932.00 \\
\hline \multicolumn{2}{|c|}{ Mean } & 61.06 & 10.60 & 57.02 & 949.73 & 58.36 & 10.32 & 49.37 & 832.93 \\
\hline \multirow{3}{*}{$\mathbf{I}_{2}$} & $\mathbf{K}_{1}$ & 60.65 & 8.66 & 56.37 & 942.16 & 57.83 & 8.59 & 51.02 & 868.40 \\
\hline & $\mathbf{K}_{2}$ & 63.93 & 9.99 & 68.67 & 1090.46 & 60.30 & 9.54 & 54.73 & 950.08 \\
\hline & $\mathbf{K}_{3}$ & 65.15 & 11.29 & 75.48 & 1265.44 & 62.60 & 11.32 & 61.09 & 1056.32 \\
\hline \multicolumn{2}{|c|}{ Mean } & 63.24 & 9.98 & 66.84 & 1099.35 & 60.24 & 9.82 & 55.61 & 958.27 \\
\hline \multirow{3}{*}{$\mathbf{I}_{3}$} & $\mathbf{K}_{1}$ & 55.42 & 6.44 & 41.54 & 697.20 & 53.13 & 6.21 & 35.29 & 614.48 \\
\hline & $\mathbf{K}_{2}$ & 58.57 & 7.75 & 46.31 & 792.24 & 55.70 & 6.69 & 46.18 & 783.92 \\
\hline & $\mathbf{K}_{3}$ & 60.42 & 8.66 & 54.84 & 920.24 & 57.93 & 8.39 & 52.54 & 895.04 \\
\hline \multicolumn{2}{|c|}{ Mean } & 58.14 & 7.62 & 47.56 & 803.23 & 55.59 & 7.10 & 44.67 & 764.48 \\
\hline \multirow{3}{*}{$\begin{array}{l}\text { Mean of } \\
\text { potassiu } \\
\text { m rates }\end{array}$} & $\mathbf{K}_{1}$ & 58.41 & 8.08 & 49.70 & 830.77 & 55.62 & 7.90 & 43.40 & 737.57 \\
\hline & $\mathbf{K}_{2}$ & 61.67 & 9.42 & 56.40 & 928.90 & 58.22 & 8.79 & 50.09 & 856.99 \\
\hline & $\mathbf{K}_{\mathbf{3}}$ & 63.37 & 10.70 & 65.32 & 1092.64 & 60.35 & 11.55 & 56.16 & 961.12 \\
\hline \multirow{3}{*}{$\begin{array}{c}\text { L.S.D } \\
\text { at } 5 \%\end{array}$} & Irrig. (I) & 2.31 & 1.02 & 1.92 & 43.90 & 2.15 & 0.98 & 1.67 & 41.33 \\
\hline & Ferti. (K) & 2.73 & 1.16 & 2.27 & 62.31 & 2.45 & 1.14 & 2.01 & 48.75 \\
\hline & I X K & 5.12 & 2.25 & 4.53 & 126.10 & 4.83 & 2.21 & 4.19 & 112.51 \\
\hline
\end{tabular}

$\left(I_{1}, I_{2}\right.$ and $\left.I_{3}\right)$ irrigation at $: 25-30,50-55$ and $75-80 \%$ of available soil moisture depletion; $\left(K_{1}, K_{2}\right.$ and $\left.K_{3}\right)$ potassium fertilizer: 0,24 and $48 \mathrm{~kg} \mathrm{~K} \mathrm{O} /$ fed., respectively. 


\subsubsection{Fruit yield per plant and per feddan}

Results obtained in Table (4) indicated that the treatment of irrigation at 50-55\% of available soil moisture depletion $\left(\mathrm{I}_{2}\right)$ led to an increase in fruit yield/plant or fed. which gave the highest values of these parameters (66.84 and 55.61 $\mathrm{g} / \mathrm{plant}$ and 1099.35 and $958.27 \mathrm{~kg} / \mathrm{fed}$. in both seasons, respectively).

This may be attributed to that fennel may easily be exposed to stress due to water deficit as mentioned by Peteropoulos et al. (2008). Such stress causes a reduction in biomass, as expressed by mean foliage and root weights, as well as leaf number per plant, and probably results from a disruption of photosynthesis, transpiration and other metabolic processes (Sarker et al., 2005).

Increasing potassium doses significantly increased fruit yield/plant and fed. in both seasons. The highest values of fruit yield/plant and fed. were obtained under $48 \mathrm{~kg} \mathrm{~K}_{2} \mathrm{O} /$ fed. in both seasons. The relative increasing of fruit yield/fed. due to $48 \mathrm{~kg} \mathrm{~K}_{2} \mathrm{O} /$ fed. were 31.4 and $17.6 \%$ when compared to 0 and $24 \mathrm{~kg} \mathrm{~K}_{2} \mathrm{O} / \mathrm{fed}$. in the first season, respectively. Similar trend was obtained in the second season. These findings are in harmony with those obtained by Amin and Patel (2001).

The interaction had a significant effect on fruit yield/plant or feddan. In general, the highest fruit yield were obtained for fennel plants irrigated at 50-55\% depletion from available soil moisture and received $48 \mathrm{~kg} \mathrm{~K}_{2} \mathrm{O} / \mathrm{fed}$. Whereas, the plants under high water stress $\left(\mathrm{I}_{3}\right)$ and without potassium fertilization recorded the lowest fruit yield.

\subsubsection{Essential oil \% and yield/plant or fed.}

Data in Table (5) revealed that both water quantities and potassium application and their interaction affected the percentage of essential oil, essential oil yield/plant or fed. in fennel in both seasons. The mean values of essential oil due to water irrigation treatments showed that increasing water depletion from 25-30 to 75$80 \%$ from available water decreased the essential oil percentage. On the other hand, the highest values of essential oil yield/plant or fed. were recorded under irrigation at $50-55 \%$ depletion from the available soil moisture. These results are in agreement with those of Singh and Ramesh (2000) who reported that water deficit stress reduced the oil yield of rosemary on a hectare basis, but oil yield on a plant fresh weight basis did not appear to be affected. Also, Zehtab et al. (2001) reported that water stress reduced oil yields of anise.

Regarding potassium effect, the current data showed that increasing potassium application up to $48 \mathrm{~kg}{ }_{2} \mathrm{O} / \mathrm{fed}$., Significantly increased the percentage of essential oil, essential oil yield/plant or fed. This result could be attributed to the important role of potassium in the physiological processes in the plant such as translocation of carbohydrates. Similar results were obtained by Younis et al. (2010).

The interaction effect between water and potassium treatments on essential oil percentage and essential oil yield/plant or fed. was significant in both seasons. The plants irrigated at $25-30 \%$ of the available soil moisture depletion and fertilized with $48 \mathrm{~kg}$ $\mathrm{K}_{2} \mathrm{O} /$ fed. showed the highest essential oil percentage. In addition, the highest essential oil yield, whether per plant or feddan was recorded under $\mathrm{I}_{2} \times \mathrm{K}_{3}$ treatment. On the other hand, the lowest essential oil percentage and essential oil yield were produced under $\mathrm{I}_{3} \times \mathrm{K}_{1}$ treatment in both seasons.

\subsubsection{Essential oil constituents}

Quantitative analysis of the chemical composition of the investigated essential oil of fennel is shown in Table (6). Gas Chromatography/Mass Spectrometry (GC/MS) analysis revealed the presence of 10 major chemicals in the oil. It can be seen from Table (6), estragole, limonene, fenchone, transanethole, $\alpha$-pinene, fenchyl acetate, myrcene, $\beta$ pinene, comphene and camphor were the major compounds in the essential oil of fennel. The main constituents in fennel seed oil were methyl chavicol (estragole) $65.49 \%$ and limonene $27.70 \%$. This result agree with those of (Braun and Franz, 1999) who found that anethole, estragole, fenchone and limonene are the major constituents of fennel essential oil which represent $93 \%$ of the fennel oil. Also, Shahat et al. (2012) assessed the essential oil variation of the aerial parts of cultivated and wild fennel (Foeniculum vulgare, Mill) in Egypt and mentioned that cultivated plants showed higher percentages of estragole, limonene, fenchone and trans-anethole, respectively. 


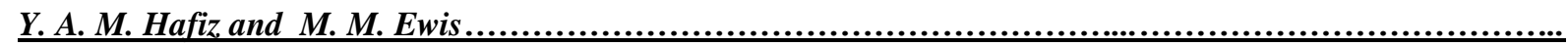

Table (5): Effect of irrigation regimes and potassium fertilization on essential oil (\%), essential oil yield (ml/plant) and (L/fed) of fennel plant in 2012/2013 and 2013/2014 seasons.

\begin{tabular}{|c|c|c|c|c|c|c|c|}
\hline \multirow{2}{*}{$\begin{array}{l}\text { Irrigation } \\
\text { regimes (I) }\end{array}$} & \multirow{2}{*}{$\begin{array}{l}\text { Potassium } \\
\text { rates } \\
\text { (K) }\end{array}$} & \multicolumn{3}{|c|}{ First season } & \multicolumn{3}{|c|}{ Second season } \\
\hline & & $\begin{array}{c}\text { Essential } \\
\text { oil } \\
(\%) \\
\end{array}$ & $\begin{array}{c}\text { Essential } \\
\text { oil yield } \\
\text { ml/plant }\end{array}$ & $\begin{array}{c}\text { Essential } \\
\text { oil yield } \\
\text { L/fed. }\end{array}$ & $\begin{array}{c}\text { Essential } \\
\text { oil } \\
(\%) \\
\end{array}$ & $\begin{array}{c}\text { Essential } \\
\text { oil yield } \\
\text { ml/plant }\end{array}$ & $\begin{array}{c}\text { Essential } \\
\text { oil yield } \\
\text { L/fed } \\
\end{array}$ \\
\hline \multirow{3}{*}{$\mathbf{I}_{1}$} & $K_{1}$ & 1.51 & 0.77 & 12.88 & 1.58 & 0.69 & 11.53 \\
\hline & $\mathbf{K}_{2}$ & 1.74 & 0.94 & 15.73 & 1.74 & 0.86 & 14.56 \\
\hline & $\mathbf{K}_{3}$ & 1.78 & 1.17 & 19.45 & 1.80 & 0.99 & 16.78 \\
\hline \multicolumn{2}{|c|}{ Mean } & 1.68 & 0.96 & 16.02 & 1.71 & 0.85 & 14.29 \\
\hline \multirow{3}{*}{$\mathbf{I}_{2}$} & $\mathbf{K}_{1}$ & 1.40 & 0.79 & 13.19 & 1.38 & 0.70 & 11.98 \\
\hline & $\mathbf{K}_{2}$ & 1.64 & 1.13 & 17.88 & 1.69 & 0.93 & 16.06 \\
\hline & $\mathbf{K}_{3}$ & 1.75 & 1.32 & 22.15 & 1.69 & 1.03 & 17.85 \\
\hline \multicolumn{2}{|c|}{ Mean } & 1.60 & 1.08 & 17.74 & 1.59 & 0.89 & 15.30 \\
\hline \multirow{3}{*}{$\mathbf{I}_{3}$} & $\mathbf{K}_{1}$ & 1.40 & 0.58 & 9.76 & 1.31 & 0.46 & 8.05 \\
\hline & $\mathbf{K}_{2}$ & 1.49 & 0.69 & 11.80 & 1.34 & 0.62 & 10.51 \\
\hline & $\mathbf{K}_{\mathbf{3}}$ & 1.60 & 0.88 & 14.72 & 1.51 & 0.79 & 13.52 \\
\hline \multicolumn{2}{|c|}{ Mean } & 1.50 & 0.72 & 12.09 & 1.39 & 0.62 & 10.69 \\
\hline Mean of & $\mathbf{K}_{1}$ & 1.44 & 0.713 & 11.94 & 1.42 & 0.62 & 10.52 \\
\hline potassium & $\mathbf{K}_{2}$ & 1.62 & 0.920 & 15.14 & 1.59 & 0.80 & 13.71 \\
\hline rates & $\mathbf{K}_{\mathbf{3}}$ & 1.71 & 1.123 & 18.77 & 1.67 & 0.94 & 16.05 \\
\hline L.S.D & Irrig.(I) & 0.07 & 0.12 & 2.02 & 0.06 & 0.11 & 2.02 \\
\hline at $5 \%$ & Ferti. (K) & 0.08 & 0.13 & 2.31 & 0.08 & 0.13 & 2.27 \\
\hline & I X K & 0.16 & 0.30 & 6.15 & 0.14 & 0.27 & 5.22 \\
\hline
\end{tabular}

$\left(I_{1}, I_{2}\right.$ and $\left.I_{3}\right)$ irrigation at : $25-30,50-55$ and $75-80 \%$ of available soil moisture depletion; $\left(K_{1}, K_{2}\right.$ and $\left.K_{3}\right)$ potassium fertilizer: 0,24 and $48 \mathrm{~kg} \mathrm{~K} \mathrm{~K}_{2} \mathrm{O}$ fed., respectively.

Table (6): Effect of irrigation regimes and potassium fertilization on essential oil constituents in oil of fennel plants.

Table (6): Effect of irrigation regimes and potassium fertilization on essential oil constituents in oil of fennel plants.
\begin{tabular}{|c|c|c|c|c|c|c|c|c|c|}
\hline \multirow{2}{*}{ Compounds } & \multicolumn{3}{|c|}{$\mathbf{I}_{\mathbf{1}}$} & \multicolumn{3}{|c|}{$\mathbf{I}_{\mathbf{2}}$} & \multicolumn{4}{|c|}{$\mathbf{I}_{\mathbf{3}}$} \\
\cline { 2 - 13 } & $\mathbf{K}_{\mathbf{1}}$ & $\mathbf{K}_{\mathbf{2}}$ & $\mathbf{K}_{\mathbf{3}}$ & $\mathbf{K}_{\mathbf{1}}$ & $\mathbf{K}_{\mathbf{2}}$ & $\mathbf{K}_{\mathbf{3}}$ & $\mathbf{K}_{\mathbf{1}}$ & $\mathbf{K}_{\mathbf{2}}$ & $\mathbf{K}_{\mathbf{3}}$ \\
\hline$\alpha$-pinene & 2.93 & 2.94 & 2.01 & 3.91 & 3.67 & 3.73 & 4.91 & 4.98 & 4.61 \\
\hline Comphene & 0.18 & 0.22 & 0.23 & 0.15 & 0.18 & 0.18 & 0.21 & 0.22 & 0.25 \\
\hline$\beta$-Pinene & 0.24 & 0.27 & 0.21 & 0.27 & 0.32 & 0.29 & 0.27 & 0.33 & 0.33 \\
\hline Myrcene & 0.33 & 0.38 & 0.39 & 0.29 & 0.36 & 0.36 & 0.29 & 0.35 & 0.34 \\
\hline Limonene & 23.42 & 23.03 & 21.55 & 22.47 & 27.70 & 25.55 & 20.76 & 17.91 & 16.68 \\
\hline Fenchone & 4.11 & 4.22 & 5.16 & 4.54 & 5.51 & 7.64 & 4.03 & 4.17 & 3.15 \\
\hline Camphor & 0.21 & 0.21 & 0.23 & 0.21 & 0.25 & 0.23 & 0.20 & 0.23 & 0.21 \\
\hline Estragole & 58.81 & 59.62 & 62.55 & 58.31 & 55.25 & 52.23 & 59.90 & 62.73 & 65.49 \\
\hline Fenchyl acetate & 1.34 & 2.03 & 2.31 & 1.41 & 1.12 & 2.58 & 2.21 & 2.39 & 2.66 \\
\hline trans-Anethole & 3.31 & 2.91 & 2.21 & 3.78 & 3.22 & 5.61 & 3.11 & 3.77 & 3.53 \\
\hline Total & 94.88 & 95.83 & 96.85 & 95.34 & 97.58 & 98.40 & 95.89 & 97.08 & 97.25 \\
\hline Unknown & 7.12 & 6.17 & 5.15 & 6.66 & 4.42 & 4.60 & 6.11 & 4.92 & 4.75 \\
\hline
\end{tabular}

$\left(I_{1}, I_{2}\right.$ andI $\left.I_{3}\right)$ irrigation at: $25-30,50-55$ and $75-80 \%$ of available soil moisture depletion; $\left(K_{1}, K_{2}\right.$ and $\left.K 3\right)$ potassium fertilizer: 0,24 and $48 \mathrm{~kg} \mathrm{~K}_{2} \mathrm{O} / \mathrm{fed}$., respectively.

As shown in Table (6), fertilization with 48 $\mathrm{kg} \mathrm{K}_{2} \mathrm{O} / \mathrm{fed} .\left(\mathrm{K}_{3}\right)$ and irrigation at $75-80 \%$ of available soil moisture depletion $\left(\mathrm{I}_{3}\right)$ recorded the highest estragole $(65.49 \%)$, fertilization with $24 \mathrm{~kg} \mathrm{~K} 2 \mathrm{O} / \mathrm{fed}$. $\left(\mathrm{K}_{2}\right)$ and irrigation at $50-55 \%$ of available soil moisture depletion $\left(\mathrm{I}_{2}\right)$ recorded the highest limonene (27.70\%), fertilization with $48 \mathrm{~kg} \mathrm{~K}_{2} \mathrm{O} / \mathrm{fed} .\left(\mathrm{K}_{3}\right)$ and irrigation at $50-55 \%$ of available soil moisture depletion $\left(\mathrm{I}_{2}\right)$ recorded the highest fenchone and trans-aenthole (7.64 and $5.61 \%$ ), respectively and fertilization with $24 \mathrm{~kg} \mathrm{~K} \mathrm{~K}_{2} \mathrm{O} / \mathrm{fed}\left(\mathrm{K}_{2}\right)$ and irrigation at $75-80 \%$ of available soil moisture depletion $\left(\mathrm{I}_{3}\right)$ recorded the highest $\alpha$-pinene. The changes in the components quality occurred by using different irrigation treatments and potassium fertilization levels may be due to their effect on the metabolism and on enzymes responsible for the components synthesis. Also, some variations may be due to the different climatic factors, handling collection and ripening times. These results are in harmony with those obtained by Ormeno et al. (2007) and Blanch et al. (2009) on Pinus halepensis. 


\subsubsection{Soil-water relations}

\subsubsection{Amount of irrigation water applied}

Data presented in Table (7) clearly show that the values of water applied increased under $\mathrm{I}_{1}$ irrigation treatment in comparison with the other two irrigation treatments of $\mathrm{I}_{2}$ and $\mathrm{I}_{3}$. The highest values were $72.26 \mathrm{~cm}\left(3034.9 \mathrm{~m}^{3} / \mathrm{fed}\right.$.) and $69.41 \mathrm{~cm}\left(2915.2 \mathrm{~m}^{3} / \mathrm{fed}\right.$.) due to $\mathrm{I}_{1}$ treatment. While, the lowest values were recorded under $\mathrm{I}_{3}$ irrigation treatment as $51.86 \mathrm{~cm}\left(2178.1 \mathrm{~m}^{3} / \mathrm{fed}\right.$.) and $48.71 \mathrm{~cm}\left(2045.8 \mathrm{~m}^{3} / \mathrm{fed}\right.$.) due to the two growing seasons, respectively. This might be due to increasing the number of irrigations accompanied with reducing irrigation period and hence increasing the amount of water applied. These results are in harmony with those obtained by Amin and Patel (2001).

\subsubsection{Water consumptive use (C.U.)}

Water consumptive use is defined as the water lost from the plant organs, specially leaves surface and namely transpiration besides that evaporated from the soil surface during the entire growing season. Data in Table (8) indicated that the amounts of seasonal water consumptive use increased in the case of frequent irrigation as in $25-30 \%$ soil moisture depletion than the two irrigation treatments. This trend showed that the increment in water consumptive use depends on the availability of soil moisture in root zone.

The relative increases of C.U. caused by 25 $30 \%$ soil moisture depletion treatment reached 19.8 and $44.4 \%$ in comparison with $50-55$ and $75-80 \%$ soil moisture depletion treatments in the first season, respectively. The same trend was obtained for the second season. Doorenbos and Pruitt (1977) gave an extensive explanation of the effect of available soil water on evapotranspiration. They stated that after irrigation or rain the water content will be reduced primarily by evapotranspiration. They added that as the soil dried, the rate of water transmitted through the soil will reduce. The effect of soil water content on evapotranspiration varies with crop and soil type, as well as water holding characteristics. These results were supported by the data obtained by Amin and Patel (2001) and Younis et al. (2010).

Respecting the effect of K-rates application, data showed slight increase in seasonal water use as K-rates increased. Such increase in evapotranspiration rate following potassium application may be due to the enhancing effect of K-fertilizer on growth which resulted in an increase in plant canopy as mentioned before consequently increased the transpiring surface and that reflected on seasonal water use. The above results are in line with those reported by Younis et al. (2010) who found an increase in water consumptive use of fennel by increasing $\mathrm{K}_{2} \mathrm{O}$ from 18 to $30 \mathrm{~kg} /$ fed..

\subsubsection{Water use efficiency (W.U.E.)}

Water use efficiency by fennel expressed as $\mathrm{kg}$ fruits produced $/ \mathrm{m}^{3}$ of water consumed as affected by irrigation regime and potassium fertilizer is presented in Table (9).

The results reveal that irrigated fennel plants at $50-55 \%$ soil moisture depletion $\left(\mathrm{I}_{2}\right)$ improved the water use efficiency in the two growing seasons and all over the two seasons. Each cubic meter of water yielded 0.63 and $0.60 \mathrm{~kg}$ fruits when the plants were irrigated at $50-55 \%$ soil moisture depletion in both seasons, respectively. On the other hand, the plants received 25-30 and $75-80 \%$ soil moisture depletion yielded 0.45 and $0.55 \mathrm{~kg}$ fruits for one cubic meter of water consumed, respectively in the first season. The corresponding values for the second season were 0.41 and $0.54 \mathrm{~kg}$ fruits $/ \mathrm{m}^{3}$ water consumed.

Regarding the effect of potassium, W.U.E. fruit yield increased by increasing potassium rate. This finding could be related to higher yield more than the increase in water consumed by fennel plant. Similar results were reported by Welch and Flannery (1985) who concluded that potassium supply increased W.U.E. of corn plants.

\subsubsection{Soil moisture extraction pattern (SMEP )}

Data of the mean values of soil moisture extraction percentage in the upper $60 \mathrm{~cm}$ soil depth as affected by soil moisture depletion and potassium fertilizer are presented in Table (10). Results indicated that the highest percentage of moisture uptake occurred at the surface layer 15 $\mathrm{cm}$ of the soil profile. Less water was extracted from the successive depths. The mean percentage values of water extracted from the upper $30 \mathrm{~cm}$ soil layer were $74.35,72.02$ and $68.72 \%$ when irrigated at 25-30, 50-55 and 75$80 \%$ soil moisture depletion, respectively, while the respective values were $25.65,27.98$ and $31.28 \%$ withdrawn from the lower $30-60 \mathrm{~cm}$. These findings could be attributed to the fact that most of plant roots are concentrated in the upper soil layers and those are the most effective in water extraction. The same results were found by El-Bably (2007) who reported that a relatively high water uptake from the top layers occurred compared to deep layers, as a result of. 


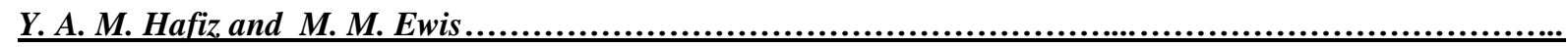

Table (7): Amount of irrigation water applied under different irrigation regimes in 2012/2013 and 2013/2014 seasons.

\begin{tabular}{|c|c|c|c|c|c|c|}
\hline \multirow{2}{*}{ Irrigation regimes (I) } & \multicolumn{2}{|c|}{ First season } & \multicolumn{2}{c|}{ Second season } & \multicolumn{2}{c|}{ Mean } \\
\cline { 2 - 7 } & $\mathrm{cm}$ & $\mathrm{m}^{3} / \mathrm{fed}$ & $\mathrm{cm}$ & $\mathrm{m}^{3} / \mathrm{fed}$ & \multicolumn{2}{c|}{$\mathrm{cm}^{3} / \mathrm{fed}$} \\
\hline $\mathrm{I}_{1}$ & 72.26 & 3034.9 & 69.41 & 2915.2 & 70.84 & 2975.1 \\
\hline $\mathrm{I}_{2}$ & 61.17 & 2568.9 & 58.60 & 2461.2 & 59.89 & 2515.1 \\
\hline $\mathrm{I}_{3}$ & 51.86 & 2178.1 & 48.71 & 2045.8 & 50.29 & 2112.0 \\
\hline Mean & 61.76 & 2594.0 & 58.91 & 2474.1 & 60.34 & 2534.1 \\
\hline
\end{tabular}

$\left(I_{1}, I_{2}\right.$ and $\left.I_{3}\right)$ irrigation at : $25-30,50-55$ and $75-80 \%$ of available soil moisture depletion.

Table (8): Water consumptive use ( $\mathrm{m}^{3} /$ fed.) as affected by irrigation regimes and potassium rates in 2012/2013and 2013/2014 growing seasons.

\begin{tabular}{|c|c|c|c|c|}
\hline \multirow{2}{*}{$\begin{array}{l}\text { Irrigation } \\
\text { regimes (I) }\end{array}$} & \multirow{2}{*}{$\begin{array}{c}\text { Potassium } \\
\text { rates }(\mathrm{K})\end{array}$} & \multicolumn{3}{|c|}{ C.U. (m³/fed.) } \\
\hline & & First season & Second season & Mean \\
\hline \multirow{3}{*}{$\mathbf{I}_{1}$} & $\mathbf{K}_{1}$ & 2006.2 & 1887.9 & 1947.1 \\
\hline & $\mathbf{K}_{2}$ & 2057.8 & 1954.3 & 2006.1 \\
\hline & $K_{3}$ & 2218.8 & 2042.7 & 2130.8 \\
\hline \multicolumn{2}{|c|}{ Mean } & 2094.3 & 1961.6 & 2028.0 \\
\hline \multirow{3}{*}{$\mathbf{I}_{2}$} & $\mathbf{K}_{1}$ & 1684.8 & 1490.8 & 1587.8 \\
\hline & $\mathbf{K}_{2}$ & 1723.3 & 1596.3 & 1659.8 \\
\hline & $\mathbf{K}_{3}$ & 1836.2 & 1674.8 & 1755.5 \\
\hline \multicolumn{2}{|c|}{ Mean } & 1748.1 & 1587.3 & 1667.7 \\
\hline \multirow{3}{*}{$\mathbf{I}_{3}$} & $\mathbf{K}_{1}$ & 1356.8 & 1235.3 & 1296.1 \\
\hline & $\mathbf{K}_{2}$ & 1468.3 & 1452.4 & 1460.4 \\
\hline & $K_{3}$ & 1526.1 & 1508.5 & 1517.3 \\
\hline \multicolumn{2}{|c|}{ Mean } & 1450.4 & 1398.7 & 1424.6 \\
\hline Mean of & $\mathbf{K}_{1}$ & 1682.6 & 1538.0 & 1610.3 \\
\hline potassium rates & $\mathbf{K}_{2}$ & 1749.8 & 1667.7 & 1708.8 \\
\hline & $\mathbf{K}_{3}$ & 1860.4 & 1742.0 & 1801.2 \\
\hline
\end{tabular}

$\left(I_{1}, I_{2}\right.$ and $\left.I_{3}\right)$ irrigation at: $25-30,50-55$ and $75-80 \%$ of available soil moisture depletion; $\left(K_{1}, K_{2}\right.$ and $\left.K_{3}\right)$ potassium fertilizer: 0 , 24 and $48 \mathrm{~kg} \mathrm{~K} \mathrm{~K}_{2} \mathrm{O} / \mathrm{fed}$., respectively.

Table (9): Water use efficiency $\left(\mathrm{kg}\right.$ fruits $\left./ \mathrm{m}^{3}\right)$ as affected by irrigation regimes and potassium levels in 2012/2013 and 2013/2014 growing seasons.

\begin{tabular}{|c|c|c|c|c|}
\hline \multirow[t]{2}{*}{ Irrigation regimes (I) } & \multirow{2}{*}{$\begin{array}{c}\text { Potassium rates } \\
(\mathbf{K})\end{array}$} & \multicolumn{3}{|c|}{ W.U.E. (kg fruits $/ \mathrm{m}^{3}$ ) } \\
\hline & & First season & Second season & Mean \\
\hline \multirow{3}{*}{$\mathbf{I}_{\mathbf{1}}$} & $\mathbf{K}_{1}$ & 0.43 & 0.34 & 0.36 \\
\hline & $\mathbf{K}_{2}$ & 0.44 & 0.43 & 0.44 \\
\hline & $\mathbf{K}_{\mathbf{3}}$ & 0.49 & 0.46 & 0.48 \\
\hline \multicolumn{2}{|c|}{ Mean } & 0.45 & 0.41 & 0.43 \\
\hline \multirow{3}{*}{$\mathbf{I}_{2}$} & $\mathbf{K}_{1}$ & 0.56 & 0.58 & 0.57 \\
\hline & $\mathbf{K}_{2}$ & 0.63 & 0.60 & 0.62 \\
\hline & $\mathbf{K}_{\mathbf{3}}$ & 0.69 & 0.63 & 0.66 \\
\hline \multicolumn{2}{|c|}{ Mean } & 0.63 & 0.60 & 0.62 \\
\hline \multirow{3}{*}{$\mathbf{I}_{\mathbf{3}}$} & $\mathbf{K}_{1}$ & 0.51 & 0.50 & 0.51 \\
\hline & $\mathbf{K}_{2}$ & 0.54 & 0.54 & 0.54 \\
\hline & $\mathbf{K}_{\mathbf{3}}$ & 0.60 & 0.59 & 0.60 \\
\hline \multicolumn{2}{|c|}{ Mean } & 0.55 & 0.54 & 0.55 \\
\hline Mean of potassium & $\mathbf{K}_{1}$ & 0.50 & 0.47 & 0.48 \\
\hline rates & $\mathbf{K}_{2}$ & 0.54 & 0.52 & 0.53 \\
\hline & $\mathbf{K}_{3}$ & 0.59 & 0.56 & 0.58 \\
\hline
\end{tabular}

$\left(I_{1}, I_{2}\right.$ and $\left.I_{3}\right)$ irrigation at : $25-30,50-55$ and $75-80 \%$ of available soil moisture depletion; $\left(K_{1}, K_{2}\right.$ and $\left.K_{3}\right)$ potassium fertilizer: 0,24 and $48 \mathrm{~kg} \mathrm{~K} \mathrm{~K}_{2} \mathrm{O} /$ fed., respectively. 
Table (10): Percentage of water uptake by fennel roots from soil layers as affected by soil moisture depletion and potassium fertilizer (average of the two seasons).

\begin{tabular}{|c|c|c|c|c|c|c|c|}
\hline \multirow{2}{*}{$\begin{array}{l}\text { Irrigation } \\
\text { regimes } \\
\text { (I) }\end{array}$} & \multirow{2}{*}{$\begin{array}{c}\text { Potassium } \\
\text { rates } \\
(\mathbf{K})\end{array}$} & \multicolumn{4}{|c|}{$\begin{array}{l}\text { Soil depth } \\
\text { (cm) }\end{array}$} & \multicolumn{2}{|c|}{$\begin{array}{c}\text { Average moisture } \\
\text { extraction }\end{array}$} \\
\hline & & 0 - 15 & $15-30$ & $30-45$ & $45-60$ & 0-30 & $30-60$ \\
\hline \multirow{3}{*}{$\mathbf{I}_{1}$} & $K_{1}$ & 47.60 & 27.11 & 18.64 & 6.65 & 74.71 & 25.29 \\
\hline & $K_{2}$ & 46.84 & 27.56 & 18.86 & 6.74 & 74.40 & 25.60 \\
\hline & $\mathbf{K}_{\mathbf{3}}$ & 45.73 & 28.21 & 19.07 & 6.99 & 73.94 & 26.06 \\
\hline \multicolumn{2}{|c|}{ Mean } & 46.72 & 27.63 & 18.86 & 6.79 & 74.35 & 25.65 \\
\hline \multirow{3}{*}{$\mathbf{I}_{2}$} & $\mathbf{K}_{1}$ & 45.54 & 26.83 & 18.76 & 8.87 & 72.37 & 27.63 \\
\hline & $K_{2}$ & 44.98 & 27.04 & 18.91 & 9.07 & 72.02 & 27.98 \\
\hline & $K_{3}$ & 44.58 & 27.09 & 19.06 & 9.27 & 71.67 & 28.33 \\
\hline \multicolumn{2}{|c|}{ Mean } & 45.03 & 26.99 & 18.91 & 9.07 & 72.02 & 27.98 \\
\hline \multirow{3}{*}{$\mathbf{I}_{3}$} & $\mathbf{K}_{1}$ & 43.36 & 26.11 & 20.22 & 10.31 & 69.47 & 30.53 \\
\hline & $\mathbf{K}_{2}$ & 42.08 & 26.59 & 20.67 & 10.66 & 68.67 & 31.33 \\
\hline & $\mathbf{K}_{\mathbf{3}}$ & 41.05 & 26.96 & 21.23 & 10.76 & 68.01 & 31.99 \\
\hline \multicolumn{2}{|c|}{ Mean } & 42.16 & 26.55 & 20.71 & 10.58 & 68.72 & 31.28 \\
\hline \multirow{3}{*}{$\begin{array}{c}\text { Mean of } \\
\text { potassium rates }\end{array}$} & $K_{1}$ & 45.50 & 26.68 & 19.21 & 8.61 & 72.18 & 27.82 \\
\hline & $K_{2}$ & 47.97 & 27.06 & 19.48 & 8.82 & 71.70 & 28.30 \\
\hline & $K_{3}$ & 43.79 & 27.42 & 19.79 & 9.01 & 71.21 & 28.79 \\
\hline
\end{tabular}

$\left(I_{1}, I_{2}\right.$ and $\left.I_{3}\right)$ irrigation at: $25-30,50-55$ and $75-80 \%$ of available soil moisture depletion; $\left(K_{1}, K_{2}\right.$ and $\left.K_{3}\right)$ potassium fertilizer: 0,24 and $48 \mathrm{~kg} \mathrm{~K} \mathrm{~K}_{2} \mathrm{O} /$ fed., respectively.

the concentrations roots in the upper layers.

For potassium fertilizer, results showed that no obvious effect on the removal moisture and the values were about the same.

\section{Conclusion}

It could be concluded that under the clay alluvial soil of Middle Egypt, irrigated fennel plants when $50-55 \%$ of available soil moisture was depleted and added $48 \mathrm{~kg} \mathrm{~K}_{2} \mathrm{O} /$ fed. were the best combination to achieve the high fruits yield ( $\mathrm{kg} / \mathrm{fed}$.) and essential oil yield (L/fed.) of fennel and improved the water use efficiency.

\section{REFERENCES}

A. E. B.(2007). (Agric. Economic,Bull) January, Edited by the Dept. of Agric. Economics and Statistics Ministry of Agric. ARE.

Abo Zied M. (2000). Egypt water resource management and policies. AlMohandeseen Magazin, pp: 528.

Amin A.U. and Patel I.S. (2001). Influence of irrigation and fertility levels on the yield, quality and economics of Rabifennel (Foeniculum vulgare, Mill). Gujarat. Agric. Univ. Res. J., 26 (2): 1-4.

Ashry M.R.K., Farag F.R.M.,Abdou S.M.M. and El-Akram M.F.I. (2012). Rationalization of irrigation water use for faba bean (Vicia faba L.). Fayoum J. Agric. Res. and Dev., 26 (1): 26-37.

Black C. A., Evans D.D., Ensminger L.E., White J.L. and Clark F.E. (1985). Methods of
Soil Analysis. Amer. Soc. of Agronomy, Inc., Madison, Wisconsin, U.S.A. Library of Congress Catalog Card Number; 6515800 Seventh Printing.

Blanch J.S., Penuelas J., Sardans J. and Liusia J. (2009). Drought, warming and soil fertilization effects on leaf volatile terpene concentrations in Pinus halepensis and a uercusilex. Acta Physiol. Plant. ,31:207218.

Braun M. and Franz G. (1999). Quality criteria of bitter fennel oil in the German Pharmacopoeia. Pharm. Pharmcoel, Lett., 9 (2): 48-51.

British Pharmacopoeia (1963). Determination of Volatile Oil in Drugs. The Pharmaceutical Press, London, UK.

Champolivier L. and Merrien A. (1996). Effects of water stress at different growth stages of Brassica napus L. var. Oleifeom yield, yield components and seed quality. Eur. J. Agron., 5: 153-160.

Doorenbos J., Kassam A.H., Bentvelsem C.L. and Branchied V. (1979). Yield response to water. Irrigation and Drainage paper, No. 33, FAO, Rome, Italy.

Doorenbos J. and Pruitt W.O. (1977). Guidelines for predicting crop water requirements. and Drainage, paper No. 24,FAO, Rome. Italy.

El- Bably Z.A. (2007). Irrigation scheduling of some maize cultivars using class A pan 
evaporation in North Delta, Egypt. Bull. Fac. Agric., Cairo Univ., 58: 222-232

Faki H.H. (1991). Water allocation and its effect on faba bean technology adoplion in Shendi area. pp: $72-75$ in Nile Valley Regional Program on Cool- Season Food Legumes and Wheat. Annual Report 1990/91,Sudan. ICARDA/ NVRPOC-017.

Fodor L and Kadlicsko B. (2006). Effect of NPK fertilization and liming on the growth of white mustard varieties. Cereal Res. Comm., 34 (11): 445-448.

Garcia G. (1978). Soil Water Engineering Laboratory Manual. Colorado State Univ., Dept., of Agric. and Chemical Engineering, Fort Collins, Colorado, U.S.A.

Hamoda S.A.F., Ibrahim M.A.A. and Emara M.A.A. (2014). Effect of irrigation intervals and NPK fertilizers on growth, yield and quality for the new cotton hybrid [Giza 83 X (Giza 75 X 5844)] X Giza80.Egypt J.Agric.Res.,92(1):111-123.

Hsiao T.C. (1973). Plant responses to water stress. Ann Rev. Plant Physiol., 24: 519570.

Israelsen O.W. and Hansen V.E. (1962). Irrigation Principles and Practices. The $3^{\text {rd }}$ Ed. John, Wiley and Sons Inc., (Pubs)New York, USA.

Jackson M.L. (1967). Soil Chemical Analysis Prentice Hall of India, Private Limited; New Delhi,India, p. 115.

Letchamo W., Hi X.U. and Gosselin A. (1995). Photosynthetic potential of Thymus vulgaris selection under 2 light regimes and 3 soil-water levels. Sci. Hort., 62: 89101.

Massoud H. (1992). Study on the essential oil in seeds of some fennel cultivars under Egyptian Environmental Conditions. Planta Med., 58 (7): 681-682.

Mengel K. and Kirkby E.A. (1987). Principles of Plant Nutrition. International Potash Institute. CH, 3048 Wohblan Fen-Bern, Switzerland.

Michael A.M. (1978). Irrigation Theory and Practice. Vikas Publishing House PVT LTD New Delhi, India.

Mohamed M.A.H. and Abdue M. (2004). Growth and oil production of fennel (Foeniculum vulgare Mill): Effect of irrigation and organic fertilization. Biol. Agric. and Hort., 22: 31-39.

Ormeno E., Mevy J.P., Vila B., Bousquet-Melou
A., Greff S., Bonin G. and Fernadez C. (2007). Water deficit stress induces different monoterpene and sesquiterpene emission chages in Mediterranean species. Relationship between terpene emissions and plant water deficit. Potential Chemosphere, 67: 276-284.

Patel B.S., Patel K.P., Patel I.D. and Patel M. (2000). Response of fennel (Foeniculum vulgare) to irrigation, nitrogen and phosphorus. Indian J. of Agron., 45: 429432.

Peteropoules S.A., Daferea D., Polissiou M.G. and Passam H.C. (2008). The effect of water deficit stress on the growth, yield and composition of essential oils of parsley. Sci, Hort., 115: 393 - 397.

Rhizopoulou S. and Diamantoglou S. (1991). Water stress induced diurnal-variations in leaf water relations, stomatal conductance, soluble sugars, lipids and essential oil content of Origanum majoranal L. J. of Hort. Sci., 66: 119-125.

Robert A. (1995). Identification of Essential Oils by Gas Chromatography-Mass Spectrometry. Allurd Pub., U.S.A.

Ruberto G., Barattata M.B., Deans S.G. and Dorman H.D.I. (2000). Antioxidant and antimicrobial activity of Foeniculum vulgare and Crithmum maritimum essential oils. Planta Medica, 66: 687-693.

Saleh M.M., Hashem F.A. and Grace M.H. (1996). Volatile oil of Egyptian sweet fennel (Foeniculum vulgare var. dulce) and its effects on isolated smooth muscles. Pharm. Pharmacol. Lett., 6: 5-7.

Sangwan N.S., Abd Farooqi A.H. and Sangwan R.S. (1994). Effect of drought stress on growth and essential oil metabolism in lemongrasses. New Phytologist, 128: 173179.

Sangwan R.S., Abd Farooqi A.H., Bansal R.P. and Sangwan N.S. (1993). Interspecific variation in physiological and metabolic responses of five species of cymbopogon to water stress. J. of Plant Physiol., 142: 618-622.

Sarker B.C., Hara M. and Uemura M. (2005). Proline synthesis, physiological responses and biomass yield of egg plant during and after repetitive soil moisture stress. Sci. Hort., 103: 387-402.

Shahat A.A., Hammouda F.M., Shams K.A. and Saleh M.A. (2012). Comparative chemical analysis of the essential oil of wild and 
cultivated fennel (Foeniculum vulgare Mill). J. Essent. Oil Bear. Pl., 15(2): 314319.

Singh M. and Ramesh S. (2000). Effect of irrigation and nitrogen on herbage, oil yield and water use efficiency in rosemary grown under semi-aird tropical conditions. J. Med. Aromat. Plant. Sci., 22(18): 659662.

Singh M., Ganesha Rao R.S. and Ramesh S. (2005). Effects of nitrogen, phosphorous and potassium on herbage, oil yield, oil quality and soil fertility status of lemongrass in a semi-aird tropical region of India. J. Hortic. Sci. Biotech., 80: 493497.

Snedecor G.W. and Cochran W.G. (1980). Statistical Methods 18th Ed. Iowa State Univ., Press,Ames, Iowa, U.S.A.

Tayel M.Y., El-Gindy A.M., Abd El-Hady M. and Ghany H.A. (2007). Effect of irrigation systems on: yield, water and fertilizer use efficiency of grape. Appli. Sci. Res., 3(5): 367-372.

Thomas T.C. and Thomas A.C. (2009). Vital role of potassium in the osmotic mechanism of stomata aperture modulation and its link with potassium deficiency. Plant Signal Behaviour, 4(3): 240-243.

Tyree M.T. and Karamanos A.J. (1981). Water stress as an ecological factor. In Plants and Their Atmospheric Environment (J. Grace \& E.D. Ford, eds.), pp. 237-261,
Blackwell Scientific; (Pub.)Oxford, U.K. Venskutonis P.R., Dapkevicius A. and Van Beek T.A. (1996). Essential oils of fennel (Foeniculum vulgare, Mill) from Lithuania. J. Essent. Oil. Res., 8 (2): 211213.

Vites F.G. (1965). Increasing water use efficiency by soil management in plant environment and efficient water use. J. Amer. Soc. Agron., 26:537-546.

Welch L.F. and Flannery R.L. (1985). Potassium nutrition of corn. Potassium in Agriculture. Proceedings of an International Symposium held 7-10 July in Atlanta ,Georgia, R. Munson(ed.), 647663.

Xiong L. and Zhu J.K. (2002). Molecular and genetic aspects of plant responses to osmotic stress. Plant, Cell and Environ., 25(2): 131-139.

Younis S. I., Rashed N.M. and Moursi E.A. (2010). Effect of water stress and potassium fertilizer on the growth, yield and composition of essential oil of fennel plant. J. Plant Production, Mansoura University, 1(7): 931-946.

Zehtab S.S., Javanshir A., Omidbaigi R., AlyAri H. and Ghassemi Golezani K. (2001). Effect of water supply and sowing date on performance and essential oil production of anise (Pimpinella anisum L.) Acta Agron. Hung., 49 (1): 75-81.

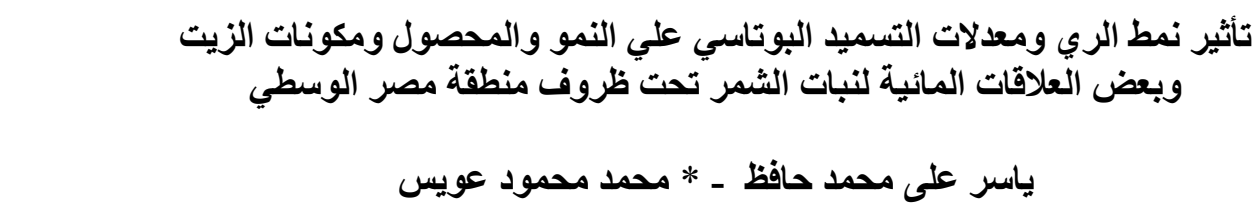

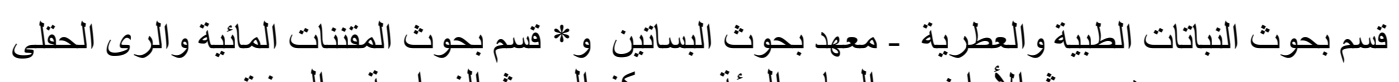

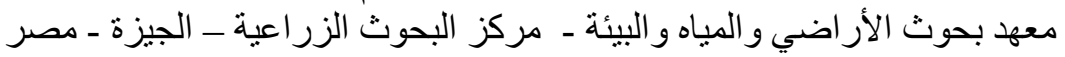

\section{ملخص}

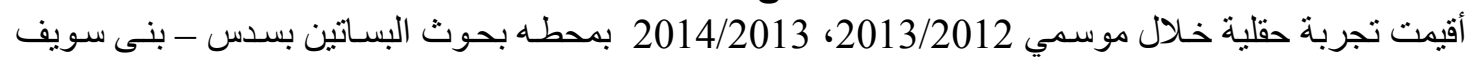

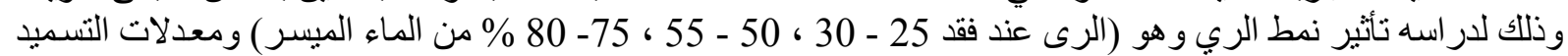

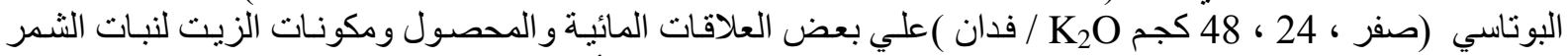

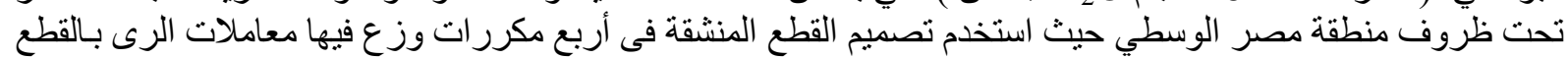
الرئيسية والتسميد البوتاسى بالقطع المنشقة. وكانت أهم النتائج التى أمكن الحصول بالفعل عليها كما يلى:- 


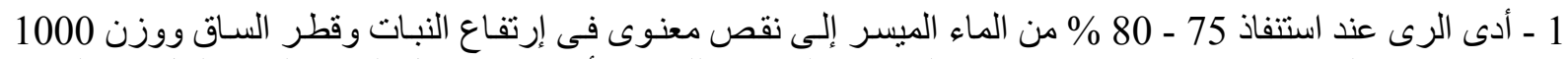

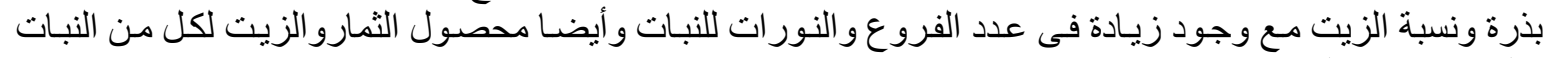
و الفذان فى كلا الموسمين.

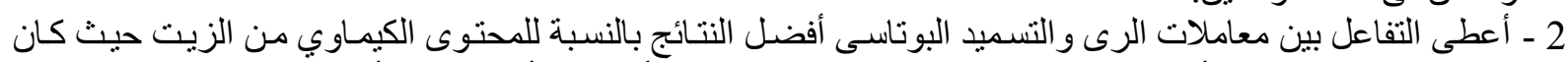

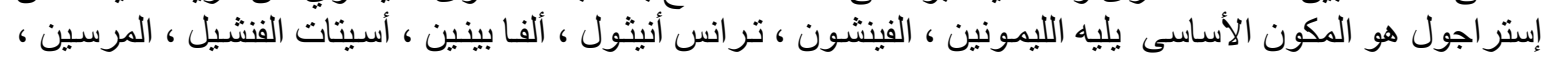

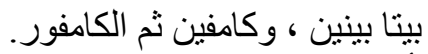

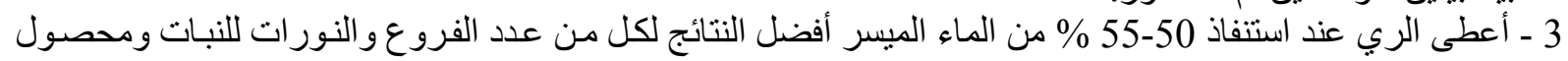

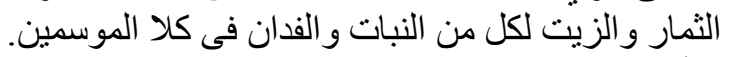

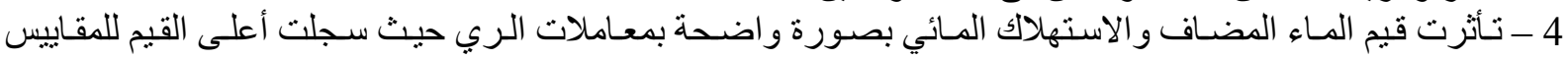

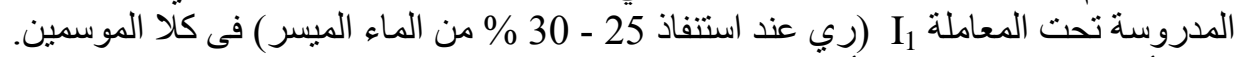

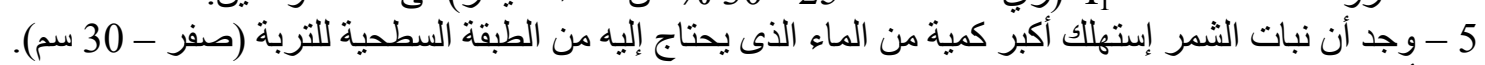

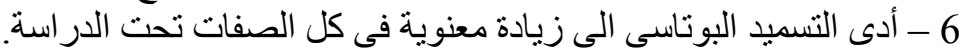

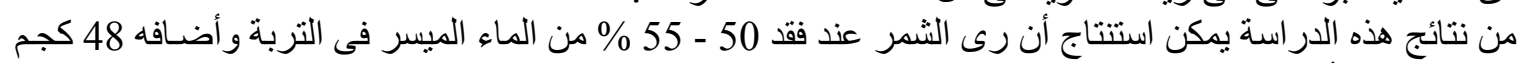

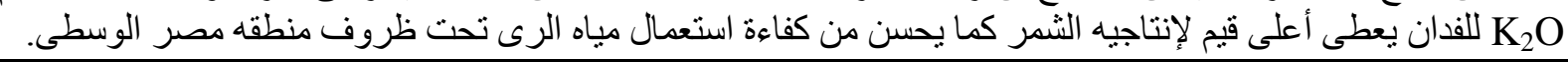
المجلة العلمية لكلية الزراعة - جامعة القاهرة - المجلا (66) العداند الثانى (أبريل 2015):142 -155. 